\title{
Posterior reversible encephalopathy syndrome in preeclampsia
}

\author{
Uma Thombarapu*, Aruna Devi Dwarampudi, Prabha Devi Kodey
}

Department of Obstetrics and Gynecology, NRI Medical College and General Hospital, Chinakakani, Mangalagiri Mandal, Guntur, Andhra Pradesh, India

Received: 13 November 2019

Accepted: 06 December 2019

\section{*Correspondence:}

Dr. Uma Thombarapu,

E-mail: umathombarapu@gmail.com

Copyright: (C) the author(s), publisher and licensee Medip Academy. This is an open-access article distributed under the terms of the Creative Commons Attribution Non-Commercial License, which permits unrestricted non-commercial use, distribution, and reproduction in any medium, provided the original work is properly cited.

\section{ABSTRACT}

Background: Posterior reversible encephalopathy is a clinico-radiological syndrome marked by headache, altered mental status, seizures, visual disturbances, and extensive white-matter changes, also known as hyper perfusion encephalopathy, brain capillary leak syndrome, and hypertensive encephalopathy. This syndrome was a possible consequence of several medical conditions but especially in pregnancy it is associated with pre-eclampsia and eclampsia. Objective of this study was to know the incidence and analyze the clinical features, biochemical, and radiological abnormalities in posterior reversible encephalopathy syndrome (PRES) as a complication of preeclampsia.

Methods: This was a one-year cross-sectional analytical study conducted at NRI general hospital, Chinakakani, Guntur of patients with the diagnosis of PRES. Data was obtained from medical records and analyzed them in terms of mean for continuous variables and percentages for categorical data.

Results: Total no of patients diagnosed as PRES were 16 out of 127 patients of preeclampsia. Among them, 14 presented with eclampsia, and two presented with severe preeclampsia and imminent symptoms of eclampsia. Headache was the most common symptom (100\%). PRES occurred at a peak SBP of $\geq 160 \mathrm{mmHg}$ in $75 \%$ cases and peak DBP of $\geq 110 \mathrm{mmHg}$ in $50 \%$ cases. Serum lactate dehydrogenase (LDH) level was $\geq 600$ in $56.25 \%$ and serum uric acid level $\geq 6$ in $50 \%$ of patients of PRES. The drug of choice was magnesium sulfate.

Conclusions: Neuroimaging abnormality is a definitive component in the diagnosis of PRES. These cerebral abnormalities are vital components in the pathogenesis of eclampsia. Considerable number of patients of preeclampsia might develop PRES even without eclampsia, with mild elevation in BP, serum LDH, and serum uric acid levels.

Keywords: Eclampsia, Posterior reversible encephalopathy syndrome, Pre-eclampsia, Serum lactate dehydrogenase, Serum uric acid

\section{INTRODUCTION}

Preeclampsia is a pregnancy-specific hypertensive disorder with multiorgan involvement. It is defined as BP $\geq 140 / 90 \mathrm{~mm} \mathrm{Hg}$ with proteinuria $\geq 300 \mathrm{mg}$ in a 24 -hour urine sample or protein /creatinine ratio $\geq 0.3$ or dip stick reading of $1+$ persistently.

(or)

\section{In the absence of proteinuria}

New-onset hypertension with the newer onset of any of the following:

- Thrombocytopenia with platelet count $\langle 1,00,000 / \mu 1$

- Renal insufficiency with serum creatinine $>1.1 \mathrm{mg} / \mathrm{dl}$ or doubling of baseline in the absence of renal disease 
- Liver involvement with Serum transaminase levels twice normal

- Pulmonary edema

- Cerebral symptoms like headache, visual disturbances, convulsions

Occurring after 20 weeks period of gestation in a previously normotensive patient. ${ }^{1}$

Worldwide, $5-10 \%$ of all pregnancies are complicated by hypertension that contributes significantly to maternal morbidity and mortality. ${ }^{2} 0.5 \%$ of mild Pre-eclampsia patients and $2-3 \%$ of severe pre-eclampsia patients might progress to eclampsia. In developed countries, the incidence of eclampsia ranges from 1 in 2000 to 3000 deliveries, whereas in developing countries, the rate is around 1 in 100 to 1 in 1700 births. $^{3-6}$

On neuroimaging in patients of eclampsia, the underlying central nervous system pathology showed subcortical edema involving the posterior lobes predominantly. This was first described in 1996 by Hinchey et al, as posterior reversible encephalopathy, a clinico-radiological syndrome which was marked by headache, altered mental status, seizures, visual disturbances, and extensive whitematter changes suggestive of posterior cerebral edema and was given the name reversible posterior leukoencephalopathy syndrome. ${ }^{7}$ It is also known as hyper perfusion encephalopathy, brain capillary leak syndrome, and hypertensive encephalopathy. This syndrome was a possible consequence of several medical conditions apart from pre-eclampsia and eclampsia such as hypertensive encephalopathy, hemolytic uremic syndrome, acute or chronic renal diseases, use of cytotoxic and immunosuppressant drugs, blood transfusion and electrolyte disturbances. ${ }^{8}$

This clinical syndrome is increasingly recognized, commonly because of the improvement and availability of brain imaging. One of the distinctive features of PRES is the reversibility of the clinical and radiological abnormalities after appropriate treatment and removal of the precipitating factor.

\section{METHODS}

It was a cross-sectional analytical study done at NRI medical college and general hospital, Chinakakani, Guntur, for a period of one year from $1^{\text {st }}$ October 2018, to $30^{\text {th }}$ September 2019. All patients diagnosed with clinical and radiological features of PRES were taken. Their demographic, clinical features, laboratory investigations, radiological abnormalities, and treatment given were analyzed by collecting the data from the medical records. Institutional ethical committee acceptance was taken before the start of the study.

\section{Inclusion criteria}

- Women >20 weeks period of gestation and <6 weeks postpartum admitted to labor room with a confirmed diagnosis of preeclampsia, eclampsia, and radio imaging showing PRES, were included in the study.

\section{Exclusion criteria}

- Non pregnant women, women with $<20$ weeks period of gestation or $>6$ weeks postpartum, without a diagnosis of preeclampsia or eclampsia and with any other co-morbidities like diabetes mellitus, renal disease, liver disorder, epilepsy was excluded.

\section{Statistical analysis}

The data of patients with the diagnosis of PRES were taken for the study. Their demographic, clinical characteristics, peak SBP, peak DBP, biochemical, radio imaging reports, and treatment given were collected and analyzed the data in terms of mean for continuous variables and percentages for categorical data are calculated.

\section{RESULTS}

Total no of deliveries during the study period were 1863 . Among them, 127 were diagnosed as pre-eclampsia, accounting for $6.8 \%$. Out of 127 pre-eclampsia patients, 59 were mild pre-eclampsia, and 68 were severe preeclampsia accounting for $46.45 \%$ and $53.54 \%$, respectively.

Total no of eclampsia patients were 18 , with an overall incidence of eclampsia being $0.96 \%$. No of cases diagnosed as PRES were 16 (Table 1), with an overall incidence of $0.85 \%$. Among 16 patients, 14 presented with eclampsia $(28.5 \%$ of antepartum eclampsia and $71.5 \%$ of postpartum eclampsia), and two patients presented with severe preeclampsia with imminent symptoms.

Among 16 patients of PRES, four were booked with hospital, and 12 patients were booked elsewhere and referred to us because of elevated BP readings or eclampsia or imminent symptoms. All patients had undergone MRI study at the institute.

Out of 16 patients 13 were primigravida / para (81.25\%). The mean age of these individuals was 22.3 years. All patients who were diagnosed as PRES presented with headache making it the most common presenting symptom, vomiting occurred in $(50 \%)$, visual disturbances like blurring of vision $(37.5 \%)$, drowsiness (25\%), epigastric pain $(18.75 \%)$, and reversible blindness occurred in $(12.5 \%)$ individuals.

PRES and eclamptic seizures occurred at an SBP of $\geq 160$ $\mathrm{mmHg}$ in 12 of 16 individuals and DBP of $\geq 110$ in 8 out of 16. Fundoscopy showed grade 1 hypertensive 
retinopathy changes in $5(31.25 \%)$, papilledema in 1 patient.

Table 1: Demographic and clinical features of 16 patients.

\begin{tabular}{|c|c|c|c|c|c|c|c|c|}
\hline No. & Age & $\begin{array}{l}\text { Period } \\
\text { of } \\
\text { gestation }\end{array}$ & $\begin{array}{l}\text { POG at the time } \\
\text { of diagnosis of } \\
\text { pres }\end{array}$ & Eclampsia & Clinical feature & $\begin{array}{l}\text { Peak } \\
\text { SBP } \\
(\mathrm{mmHg})\end{array}$ & $\begin{array}{l}\text { Peak } \\
\text { DBP } \\
(\mathrm{mmHg})\end{array}$ & Fundoscopy \\
\hline 1. & 23 & $\begin{array}{l}37+2 \\
\text { weeks }\end{array}$ & $\begin{array}{l}\text { P1L1, } \\
\text { POD-4 }\end{array}$ & PPE & $\begin{array}{l}\text { Headache, blindness } \\
\text { blurring of vision }\end{array}$ & 170 & 90 & Papilledema \\
\hline 2. & 20 & $\begin{array}{l}34+5 \\
\text { weeks }\end{array}$ & Primi with twins & APE & Headache & 200 & 100 & Normal \\
\hline 3. & 21 & 39 weeks & $\begin{array}{l}\text { P2L2, } \\
\text { PND-5 }\end{array}$ & PPE & $\begin{array}{l}\text { Headache, blurring } \\
\text { of vision }\end{array}$ & 180 & 100 & GR 1 HTNR \\
\hline 4. & 21 & 25 weeks & $\begin{array}{l}\text { A1 } \\
\text { PAD-1 }\end{array}$ & $\begin{array}{l}\text { no } \\
\text { eclampsia }\end{array}$ & $\begin{array}{l}\text { Headache, visual } \\
\text { disturbance }\end{array}$ & 150 & 90 & Normal \\
\hline 5. & 20 & $\begin{array}{l}38+2 \\
\text { weeks }\end{array}$ & $\begin{array}{l}\text { P1L1, } \\
\text { PND-5 }\end{array}$ & PPE & $\begin{array}{l}\text { Headache, blindness } \\
\text { Blurring of vision }\end{array}$ & 170 & 110 & Normal \\
\hline 6. & 19 & $\begin{array}{l}37+6 \\
\text { weeks }\end{array}$ & Primi & APE & $\begin{array}{l}\text { Headache, epigastric } \\
\text { pain, vomiting, } \\
\text { blurring of vision }\end{array}$ & 170 & 110 & Normal \\
\hline 7. & 26 & $\begin{array}{l}25+4 \\
\text { weeks }\end{array}$ & Primi & APE & $\begin{array}{l}\text { Headache, epigastric } \\
\text { pain, vomiting }\end{array}$ & 170 & 110 & Gr 1 HTNR \\
\hline 8. & 24 & $\begin{array}{l}39+3 \\
\text { weeks }\end{array}$ & $\begin{array}{l}\text { P1L1, } \\
\text { POD -5 }\end{array}$ & PPE & Headache & 140 & 80 & Normal \\
\hline 9. & 20 & 40 weeks & $\begin{array}{l}\text { P1L1, } \\
\text { POD-6 }\end{array}$ & PPE & $\begin{array}{l}\text { Headache, } \\
\text { drowsiness, } \\
\text { Blurring of vision }\end{array}$ & 160 & 100 & Normal \\
\hline 10. & 22 & $\begin{array}{l}31+3 \\
\text { weeks }\end{array}$ & G2A1 & APE & $\begin{array}{l}\text { Headache, epigastric } \\
\text { pain, vomiting }\end{array}$ & 140 & 110 & Normal \\
\hline 11. & 21 & 39 weeks & $\begin{array}{l}\text { P1L1A1 } \\
\text { POD -8 }\end{array}$ & PPE & Headache, vomiting & 140 & 100 & Gr 1 HTNR \\
\hline 12. & 20 & $\begin{array}{l}39+1 \\
\text { weeks }\end{array}$ & $\begin{array}{l}\text { P1L1, } \\
\text { POD -6 }\end{array}$ & PPE & $\begin{array}{l}\text { Headache, vomiting, } \\
\text { drowsiness }\end{array}$ & 180 & 110 & Normal \\
\hline 13. & 19 & $\begin{array}{l}28+5 \\
\text { weeks }\end{array}$ & $\begin{array}{l}\text { P1L1, } \\
\text { PND-5 }\end{array}$ & PPE & Headache, vomiting & 170 & 110 & Normal \\
\hline 14. & 25 & 33 weeks & $\begin{array}{l}\text { P1D1, } \\
\text { PND-1 }\end{array}$ & PPE & $\begin{array}{l}\text { Headache, vomiting, } \\
\text { drowsiness }\end{array}$ & 190 & 120 & Normal \\
\hline 15. & 31 & 26 weeks & $\begin{array}{l}\text { A1 } \\
\text { PAD-1 }\end{array}$ & $\begin{array}{l}\text { no } \\
\text { eclampsia }\end{array}$ & $\begin{array}{l}\text { Headache, vomiting, } \\
\text { drowsiness }\end{array}$ & 190 & 130 & Gr 1 HTNR \\
\hline 16. & 25 & 32 weeks & $\begin{array}{l}\text { P1L2, } \\
\text { POD-0 }\end{array}$ & PPE & Headache & 170 & 100 & Gr 1 HTNR \\
\hline
\end{tabular}

POG: period of gestation, PRES: posterior reversible encephalopathy syndrome, APE: antepartum eclampsia, PPE: postpartum eclampsia, HTNR: hypertensive retinopathy, SBP: systolic blood pressure, DBP: diastolic blood pressure.

Table 2: Biochemical abnormalities of the patients of PRES.

\begin{tabular}{|c|c|c|c|c|c|c|c|c|}
\hline No. & $\mathbf{H b} \%$ & $\begin{array}{l}\text { Platelet } \\
\text { count }\end{array}$ & $\begin{array}{l}\text { Serum } \\
\text { creatinine }\end{array}$ & LDH & $\begin{array}{l}\text { Serum uric } \\
\text { acid }\end{array}$ & AST (SGOT) & ALT (SGPT) & $\begin{array}{l}\text { Urine } \\
\text { albumin }\end{array}$ \\
\hline 1. & 10.9 & 3 & 0.7 & 650 & 5.2 & 40 & 25 & $1+$ \\
\hline 2. & 10.5 & 3.3 & 0.8 & 480 & 6.2 & 43 & 16 & $1+$ \\
\hline 3. & 11.6 & 4.7 & 0.5 & 560 & 5.4 & 45 & 18 & $2+$ \\
\hline 4. & 7.3 & 2 & $1.6 *$ & 604 & 10.4 & 76 & 22 & $2+$ \\
\hline 5. & 9.6 & 2.6 & 0.7 & 874 & 8.4 & 47 & 37 & $3+$ \\
\hline 6. & 10 & 2.1 & 0.9 & 451 & 3.7 & 21 & 24 & $1+$ \\
\hline 7. & 9.4 & 2.1 & 0.8 & 529 & 7.3 & 115 & 126 & $2+$ \\
\hline 8. & 12.5 & 2.1 & 0.6 & 659 & 2.3 & 17 & 25 & $1+$ \\
\hline 9. & 10.9 & 2.6 & 0.6 & 520 & 5.6 & 15 & 11 & $2+$ \\
\hline 10. & 5.7 & 0.9 & $0.6 * *$ & 4460 & 9.1 & 838 & 276 & $3+$ \\
\hline
\end{tabular}




\begin{tabular}{|llllllll|l|}
\hline No. & Hb $\%$ & $\begin{array}{l}\text { Platelet } \\
\text { count }\end{array}$ & $\begin{array}{l}\text { Serum } \\
\text { creatinine }\end{array}$ & LDH & $\begin{array}{l}\text { Serum uric } \\
\text { acid }\end{array}$ & AST (SGOT) & ALT (SGPT) & $\begin{array}{l}\text { Urine } \\
\text { albumin }\end{array}$ \\
\hline 11. & 11.3 & 4.3 & 0.5 & 781 & 5 & 29 & 24 & $1+$ \\
\hline 12. & 10.2 & 4.1 & 0.9 & 360 & 8.4 & 20 & 12 & $1+$ \\
\hline 13. & 9.2 & 2.9 & 0.9 & 600 & 7.8 & 91 & 66 & $4+$ \\
\hline 14. & 12.7 & 1.6 & 0.6 & 701 & 4.4 & 26 & 23 & $3+$ \\
\hline 15. & 15.3 & 1.7 & 0.7 & 1335 & 7.8 & 63 & 26 & $4+$ \\
\hline 16. & 10.2 & 2.5 & 0.8 & 408 & 5.5 & 22 & 10 & $4+$ \\
\hline
\end{tabular}

*Sr Ceatinine, ** HELLP Syndrome. LDH: lactate dehydrogenase, AST: Aspartate aminotransferase, SGOT: serum glutamic oxaloacetic transaminase, ALT: alanine transaminase, SGPT: serum glutamic pyruvic transaminase.

Table 3: Radiological findings, treatment modality, and mode of termination in the patients of PRES.

\begin{tabular}{|c|c|c|c|c|c|}
\hline \multirow{2}{*}{ Site of lesion } & \multicolumn{4}{|c|}{ Treatment modality } & \multirow{2}{*}{$\begin{array}{l}\text { Mode of } \\
\text { termination }\end{array}$} \\
\hline & $\mathrm{MgSo}_{4}$ & Anti-HTN & Anti-epileptic & Mannitol & \\
\hline $\begin{array}{l}\text { b/l parieto occipital and } \\
\text { capsuloganglionic area }\end{array}$ & Given & T. Labetalol & $\begin{array}{l}\text { Levetiracetam } \\
\text { Clobazam }\end{array}$ & Given & LSCS \\
\hline $\begin{array}{l}\text { b/l temporal, frontal, } \\
\text { occipital, parietal }\end{array}$ & Given & T. Labetalol & Levetiracetam & Given & $\begin{array}{l}\text { Primary emergency } \\
\text { LSCS }\end{array}$ \\
\hline b/l parieto occipital & Given & Stamlodipine & Levetiracetam & & NVD \\
\hline $\begin{array}{l}\text { b/l occipital lobes up to } \\
\text { subcortical white matter }\end{array}$ & Given & Stamlodipine & & & $\begin{array}{l}2^{\text {nd }} \text { trimester induced } \\
\text { abortion }\end{array}$ \\
\hline $\begin{array}{l}\text { b/l occipital, lt posterior } \\
\text { parietal }\end{array}$ & Given & $\begin{array}{l}\text { T. Labetalol, } \\
\text { Nifedipine, } \\
\text { Stamlodipine }\end{array}$ & Levetiracetam & & NVD \\
\hline $\begin{array}{l}\text { b/l frontal, occipital, } \\
\text { parietal }\end{array}$ & Given & $\begin{array}{l}\text { T. Labetalol, } \\
\text { Nifedipine, } \\
\text { Stamlodipine }\end{array}$ & $\begin{array}{l}\text { Levetiracetam } \\
\text { Fentanyl }\end{array}$ & & $\begin{array}{l}\text { Primary emergency } \\
\text { LSCS }\end{array}$ \\
\hline $\begin{array}{l}\text { b/l temporal, frontal, } \\
\text { occipital,parietal, lt thalamus }\end{array}$ & Given & $\begin{array}{l}\text { T. Labetalol, } \\
\text { Nifedipine, } \\
\text { Stamlodipine }\end{array}$ & Levetiracetam & Given & $\begin{array}{l}2^{\text {nd }} \text { trimester induced } \\
\text { abortion }\end{array}$ \\
\hline $\begin{array}{l}\mathrm{b} / \mathrm{l} \text { occipital, } \\
\text { parietal, It temporal, } \\
\text { frontal,cerebellar }\end{array}$ & Given & $\begin{array}{l}\text { Stamlodipine } \\
\text { Nifedipine. }\end{array}$ & & & LSCS \\
\hline b/l parieto occipital & Given & Labetalol & Levetiracetam & Given & LSCS (thick MSL) \\
\hline b/l parieto occipital & Given & & Levetiracetam & & $\begin{array}{l}\text { Primary emergency } \\
\text { LSCS }\end{array}$ \\
\hline $\begin{array}{l}\mathrm{b} / \mathrm{l} \text { parieto occipital and } \\
\text { cerebellar hemispheres }\end{array}$ & Given & $\begin{array}{l}\text { Labetalol } \\
\text { Stamlodipine }\end{array}$ & & & LSCS \\
\hline $\begin{array}{l}\text { b/l posterior parietal and } \\
\text { occipital lobes and lt frontal } \\
\text { lobe }\end{array}$ & Given & Nifedipine. & $\begin{array}{l}\text { Levetiracetam } \\
\text { Clobazam }\end{array}$ & Given & LSCS \\
\hline $\begin{array}{l}\text { b/l frontal,temporo-parieto- } \\
\text { occipital lobes ,peri } \\
\text { ventricular white matter, b/l } \\
\text { lentiform nuclei,b/lthalami }\end{array}$ & Given & $\begin{array}{l}\text { Labetalol, } \\
\text { Nifedipine }\end{array}$ & $\begin{array}{l}\text { levetiracetam } \\
\text { Clobazam }\end{array}$ & & labour preterm \\
\hline $\mathrm{b} / \mathrm{l}$ parietal & Given & $\begin{array}{l}\text { Labetalol } \\
\text { Stamlodipine }\end{array}$ & Levetiracetam & Given & $3^{\text {rd }}$ trimister IUD \\
\hline $\begin{array}{l}\mathrm{b} / \mathrm{l} \text { fronto parietal,occipital } \\
\text { and rt temporal lobe }\end{array}$ & Given & $\begin{array}{l}\text { Labetalol, } \\
\text { Clindipine, } \\
\text { Stamlodipine }\end{array}$ & Levetiracetam & Given & $\begin{array}{l}2^{\text {nd }} \text { trimister induced } \\
\text { abortion }\end{array}$ \\
\hline b/l parietal and occipital & Given & $\begin{array}{l}\text { Labetalol } \\
\text { Stamlodipine }\end{array}$ & Levetiracetam & & $\begin{array}{l}\text { primary preterm } \\
\text { emergency LSCS }\end{array}$ \\
\hline
\end{tabular}

Nine of 16 patients of PRES showing Serum LDH Level $\geq 600$ accounting to $(56.25 \%)$ (Table 2). Among these nine individuals with serum LDH $>600$, severe BP recordings with SBP of $\geq 160$ or DBP of $\geq 110$ were noted 
in 7 individuals $(77.7 \%)$. Eight out of 16 showing serum uric acid level $\geq 6(50 \%)$ among these eight individuals SBP was $\geq 160$ or DBP was $\geq 110$ in 7 individuals $(87.5 \%)$. Liver enzymes were elevated in 4 Individuals (25\%), taking twice the level of normal SGOT and SGPT as baseline. Urine albumin was $>1+$ in 10 individuals $(62.5 \%)$. One individual showed features suggestive of HELLP syndrome with elevated liver enzymes, low platelet count, and severe anemia. Sr. Creatinine was $\geq 1.1$ in one individual.

MRI showed edema mainly involving the posterior cerebral regions (Table 3 ). Other regions of the brain involved were thalamus, capsuloganglionic area, frontal lobes, pons, and cerebellar hemispheres. Magnesium sulfate was given to all the 16 patients by Pritchard's regimen. Along with magnesium sulfate, levetiracetam, and clobazam were required to treat seizures in 13 patients. Injection Mannitol was administered in 7 cases who did not respond to magnesium sulfate alone and who had extreme irritability and visual disturbances. Antihypertensives like Inj/Tab labetalol, Tab stamlodipine, or Tab nifedipine were given in required doses based on the severity.

Mode of delivery was vaginal in $25 \%$, LSCS in $56.25 \%$ for different obstetric indications.

There was no residual morbidity and maternal mortality in the present study until the time of discharge.

\section{DISCUSSION}

Wagner et al, proposed that PRES and eclampsia are pathophysiologically related. ${ }^{9}$ Eclamptic patients may have seizure onset at lower blood pressures than patients with hypertensive encephalopathy. The two most accepted theories in the pathogenesis of PRES are vasogenic and cytotoxic theory. Vasogenic edema occurs due to sudden elevation of $\mathrm{SBP}>150 \mathrm{mmHg}$, which affects the intrinsic myogenic vasoconstriction. This leads to hyperperfusion and edema. ${ }^{10}$ Cytotoxic edema is due to a sudden rise in BP, leading to vasospasm resulting in hypoperfusion, hypoxia, and ischemia, which leads to the development of cytotoxic edema and endothelial cell damage with or without actual cerebral infarction. ${ }^{11}$

In this study, the demographic, clinical features, biochemical, radiological abnormalities, and treatment modalities opted for the cases of PRES were analyzed.

All patients were less than 30 years of age except one. Most of them were primigravida /para presented antenatally or postnatally. Only 3 patients (3/16) presented at less than 28 weeks period of gestation and all others are in the 3 rd trimester. Among these 3 patients, 2 patients did not have eclampsia. They presented with headache, visual disturbances, and vomiting with elevated BP has undergone MRI and diagnosed as PRES.
Among 16 patients of PRES, 14 presented with eclampsia, and 2 patients presented with severe preeclampsia with imminent symptoms. Out of 14 eclampsia patients, 4 had antepartum eclampsia, and 10 patients had postpartum eclampsia. 14 out of 18 patients of eclampsia $(77.7 \%)$ were diagnosed to have PRES in comparison to Brewer et al, study on 47 eclamptic patients which revealed PRES in 46 cases $(97.8 \%)$, and it was suggested that PRES is a vital component in the pathogenesis of eclampsia. ${ }^{12}$

An overall incidence of eclampsia being $(0.96 \%)$, in comparison to the study done by Nobis et al, the incidence of eclampsia in India is about $1.5 \%{ }^{13}$

In this study headache was the most common presenting symptom (100\%) followed by vomitings $(50 \%)$, visual disturbance like blurring of vision $(37.5 \%)$, drowsiness $(25 \%)$, epigastric pain $(18.75 \%)$, and reversible blindness occurred in $(12.5 \%)$ individuals when compared to study by Brewer et al, (47 patients) noted that headache was the most common presenting symptoms in $87.2 \%$ of the patients, altered mental status occurred in (51.1\%), involvement of vision in (34\%), nausea and vomitings in $(19.1 \%)$ of patients. ${ }^{12}$

PRES and eclamptic seizures occurred at an SBP of $\geq 160$ $\mathrm{mmHg}$ in 12 of $16(75 \%)$ individuals and DBP of $\geq 110$ in 08 out of $16(50 \%)$. Fundoscopy showed grade 1 hypertensive retinopathy changes in 5 (31.25\%), papilledema in 1 patient.

Study showed elevated serum LDH in $56.25 \%$ and uric acid levels in $50 \%$ patients of PRES. LDH is an intracellular enzyme responsible for the interconversion of lactate and pyruvate in the cells. LDH levels are more inside the cells than in plasma. Uric acid, which is an end product of purine metabolism, was filtered through glomeruli, and most of it is completely reabsorbed in proximal convoluted tubules. Endothelial dysfunction leads to elevated levels of LDH and uric acid indicative of the cellular damage and dysfunction; thus, they can be regarded as early biochemical markers to identify the occurrence of the complications of preeclampsia and reflects the severity of the disease. ${ }^{14,15}$

Posterior circulation is commonly involved in PRES; this was similar to WS Bartynski's study. ${ }^{11}$ The parieto occipital region is most commonly involved (100\%), similar to a study by Mckinney et al, showing involvement of the parieto occipital region in $98.7 \% .^{16}$

$\mathrm{MgSo}_{4}$, which controls the eclamptic seizures, was also thought to reduce the cerebral perfusion pressure. So, it has been used not only to control but also to prevent seizures. ${ }^{9}$ In this study, Inj $\mathrm{MgSo}_{4}$ was used to control and avoid eclamptic convulsions and in selected cases with extreme irritability anti-edema agent like mannitol was used which was very similar to study by Suman 
Sardesai et al, which concluded that Inj $\mathrm{MgSO}_{4}$ was the drug of choice. ${ }^{17}$

\section{CONCLUSION}

Neuroimaging abnormality is a core component in the diagnosis of PRES, which indicate cytotoxic or vasogenic edema in the cerebral vasculature. In some patients, even with mild elevation of BP, there may be symptoms of PRES with or without eclampsia. Elevated serum LDH and serum uric acid, which indicate cellular damage, also acts as early biochemical markers for the prediction of severity of preeclampsia, leading to PRES.

\section{Funding: No funding sources}

Conflict of interest: None declared

Ethical approval: The study was approved by the Institutional Ethics Committee

\section{REFERENCES}

1. ACOG; Hypertension in pregnancy. Report of the American College of Obstetricians and Gynecologists' Task Force on Hypertension in Pregnancy. Obstet Gynecol. 2013;122(5):1122-31.

2. Cunningham FG, Leveno KJ, Bloom SL, Dashe SJ, Hofman BL, Casey BM, et al. Williams Obstetric $25^{\text {th }}$ ed. New York NY: McGraw Hill Medical Publishing Division, Chapter 40, Hypertensive disorders in pregnancy; 2018:710-754.

3. Andersgaard AB, Herbst A, Johansen M, Ivarsson A, Ingemarsson I, Langhoff-Roos J, et al. Eclampsia in Scandinavia: incidence, substandard care, and potentially preventable cases. Acta Obstet Gynecol Scand. 2006;85(8):929-36.

4. Ventura SJ, Martin JA, Curtin SC, Mathews TJ, Park MM. Births: final data for 1998. Natl Vital Stat Rep. 2000;48(3):1-100.

5. Misra R, Donald's I. Practical Obstetrics problems. $7^{\text {th }}$ edition, Greater Noida; Wolter Kluwer India Pvt. Ltd. Chapter 8: Hypertensive Disorders; 2014:42-175.

6. Chua S, Arulkumaran S, Eclampsia- no room for complacency. Singapore Med J. 1995;36(5):470-1.

7. Hinchey J, Chaves C, Appignani B, Breen J, Pao L, Wang A, et al. A reversible posterior leukoencephalopathy syndrome. $\mathrm{N}$ Engl J Med. 1996;334(8):494-500.
8. Stott VL, Hurrell MA, Anderson TJ. Reversible posterior leukoencephalopathy syndrome: a misnomer reviewed. Int Med J. 2005;35(2):83-90.

9. Wagner SJ, Acquah LA, Lindell EP, Craici IM, Wingo MT, Rose $\mathrm{CH}$, et al. Posterior reversible encephalopathy syndrome and eclampsia: Pressing the case for more aggressive blood pressure control. Mayo Clin Proc. 2011;86:851-6.

10. Bartynski WS. Posterior reversible encephalopathy syndrome-part 2: controversies surrounding pathophysiology of vasogenic edema Am J Neuroradiol. 2008;29(6):1043-9.

11. Bartynski WS. Posterior reversible encephalopathy syndrome- part 1: fundamental imaging and clinical features. Am J Neuroradiol. 2008;29(6):1036-42.

12. Brewer J, Owens MY, Wallace K, Reeves AA, Morris R, Khan M, et al. Posterior reversible encephalopathy syndrome in 46 out of 47 patients with eclampsia. Am J Obstet Gynecol. 2013;208:468.e1-6.

13. Nobis PN, Hajong A. Eclampsia in India through the decades. Obstet Gynaecol India. 2016;66(Suppl 1):172-6.

14. Joseph L, George M, Alex A. A review on the estimation of serum LDH and uric acid in hypertensive versus normal pregnant women and its correlation with maternal outcome in a tertiary care hospital. Int J Ther Appli. 2016;32:35-7.

15. Gao B. Serum LDH as an early marker of posterior reversible encephalopathy syndrome. Anaesth Intens Care. 2012;40:902-3.

16. McKinney AM, Short J, Truwit CL, McKinney ZJ, Kozak OS, SantaCruz KS, et al. Posterior reversible encephalopathy syndrome: incidence of atypical regions of involve-ment and imaging findings. AJR Am J Roentgenol. 2007;189:904-12.

17. Sardesai S, Dabade R, Deshmukh S, Patil P, Pawar S, Patil A, et al. Posterior reversible encephalopathy syndrome (PRES): evolving the mystery of eclampsia. J Obstet Gynecol India. 2019;69:334.

Cite this article as: Thombarapu U, Dwarampudi AD, Kodey PD. Posterior reversible encephalopathy syndrome in preeclampsia. Int J Reprod Contracept Obstet Gynecol 2020;9:358-63. 